ULDIS VIKMANIS, INGRIDA RUMBA, ARNIS VIKSNA

\title{
PAR PROFESORA PĒTERA SNIKERA DARBĪBU LU MEDICĪNAS FAKULTĀTĒ
}

Profesors Pēteris Sniķers (1875-1944) bija viens no LU Medicīnas fakultātes dibinātājiem, Ādas un venerisko slimību katedras un klīnikas vadītājs un divus termiņus - arī dekāns. Viṇa ieguldījums fakultātes izaugsmẽ ir nozīmīgs un neapšaubāms.

Pārskatot profesoram veltīto biogrāfisko literatūru, jākonstatē, ka viṇa dzīves un darbības aplūkojumam līdz šim nepietiekami ir izmantoti arhīvu dokumenti, tālab ši raksta nolūks ir tieši šâda veida avotos meklēt vēl neizzinātas vai nepietiekami aplūkotas detalas un nianses P. Sniķera daudzpusīgajā darbībā. Plašāk par viṇu pēckara literatūrā pirmie rakstīja I. Gērke un J. Stradiņ̧̌šl, gan tolaik saprotamu iemeslu pẽc izlaižot P. Sniķera kā Latvijas armijas ârsta generāla darbỉbu, ko savukārt tautas atmodas laikā pirmais aplūkoja A. Vīksna². Visplašāk par vinuu ir rakstijušsi A. Miltinš un V. Miltiņš, apkopojumu sniedzot 1998. gadā ${ }^{3}$, tiesa gan, labu gribēdami, nespējot izvairīties no pārslavināšanas un nekritiskas pieejas, kas vēl jaušamāk izpaužas P. Sniḳera 125 gadu jubilejas izdevumă ${ }^{4}$, kurā, līdzās pārējam, viņš jau nosaukts par "folklorizētu personu".

Šai rakstā, kas tapis jubilejas atskaņā, uzmanỉba galvenokārt tiek pievērsta diviem jautājumiem: 1) P. Sniķera avansēŠanas gaitai fakultātē un 2) fakultātes mācību plāniem un programmām laika ritējumā.

1 Герке И. М., Страдынь Я. П. Из истории дермато-венерологии Латвии // Из истории медищины. - P., 1962. - Т. 4. - С. 87-93.

2 Vīksna A. Pirmais latviešu ārsts generālis // Latvijas Ārsts. - 1990. - 3. nr. -63.-65. Ipp.

3 Miltiņ̌ V., Miltinğ A. Pēteris Sniḳers. - R., 1998. - 113 lpp.

4 Profesoram un generālim Pēterim Sniḳeram - 125 // Starptautiska konference. - R., 2000. $-86 \mathrm{lpp}$. 


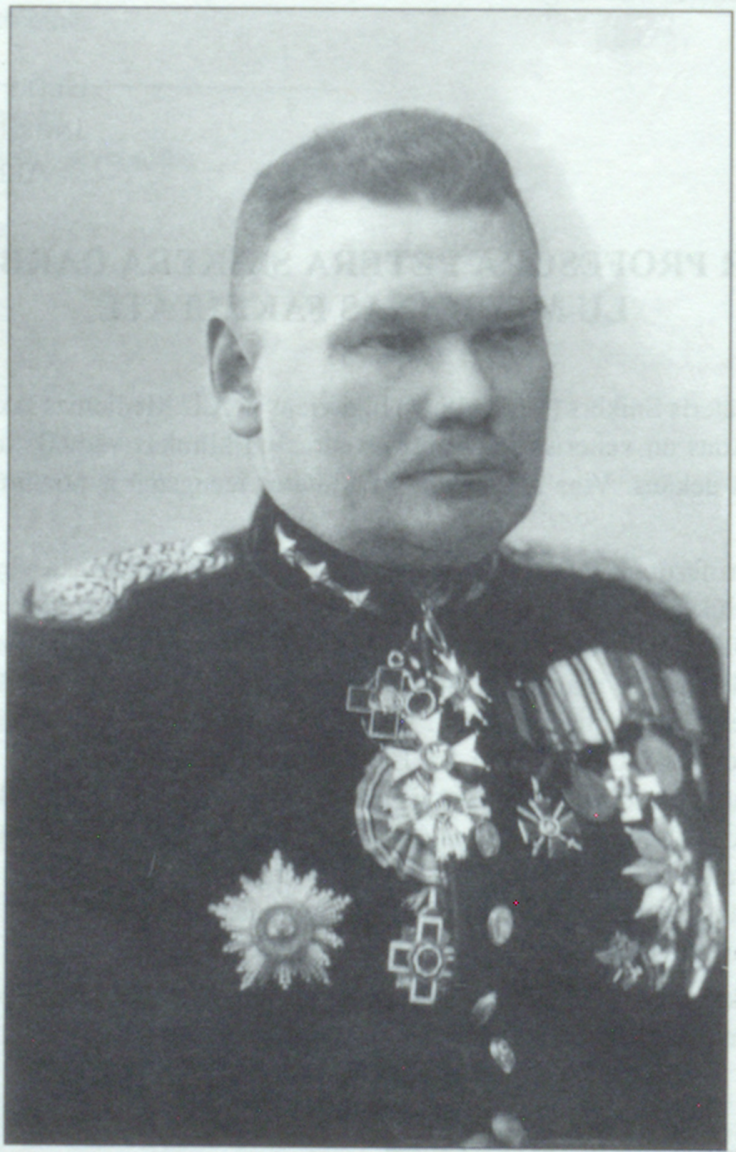

Ārsts ġenerālis profesors Pēteris Sniḳers (1875-1944) 
P. Sniķers bija viens no LU un tās Medicīnas fakultātes dibināšanas rosinātājiem un So domu pauda jau 1910. gadā, tiesa gan, tolaik vēl anonīmi ${ }^{5}$.

Kad fakultāte jau tapa reāli, un tas notika 1919. gada rudenī, viņš visdzīvāk piedalījās tās struktūras veidošanā un, gluži dabiski, jau kādã no pirmām fakultātes sēdēm, 1919. gada 9. decembrī, vienbalsīgi tika proponēts par profesoru' ${ }^{6}$ taču, kā vēlāk izrādījās, nebija guvis oficiālu apstiprinājumu augstākstâvošās instancēs Augstskolā un Izglītības ministrijā. Šeit gan jânemem vērã konkrētā tã laika situãcija - ārsts pulkvedis P. Sniḳers kā Armijas sanitārās pārvaldes priekšnieks bija ārkārtīgi aiznnemts Latvijas atbrīvošanās cīñās, kuras vēl nebija beigušãs; Ādas un venerisko slimību katedra vēl nebija izveidota un lekcijas studentiem šai priekšmetā lasîtas netika un, gluži dabiski, bija jāpaiet vēl kādam laikam, lai pie š̃ jautājuma atgrieztos atkārtoti.

Tas pienāca jau pēc gada, kad pirmie divi kursi bija nokomplektēti un strādāja pilnā sparā, tālab fakultāte pievērsās klīnisko priekšmetu docētāju sastâva veidošanai vecākos kursos. P. Sniḳera akadēmisko virzību šai laikā iespējams konstatēt pēc fakultātes sēžu protokoliem un citiem dokumentiem, kas galvenokārt saglabājušies Latvijas Valsts vēstures arhīvā (LVVA).

P. Sniḳera iesniegto darbu recenzēšanai fakultāte 1920. gada 29. novembrī izveidoja komisiju, kuras sastāvā ietilpa dekāns, bioḳīmiķis profesors Roberts Krimbergs (1874-1941), patologs profesors Ernests Paukulis (1872-1941) un ķirurgs docents (vēlāk - profesors) Jēkabs Alksnis (1870-1957) ${ }^{7}$.

Drīz pēc tam docents J. Alksnis iesniedza savu atsauksmi, kuru kã savdabīgu laikmeta dokumentu šeit nepieciešams citēt pilnībā. Lūk, ko rakstīja recenzents:

"Dr. med. Snikers iesniedzis 21 zinātnisku darbu, no kuriem 15 ir stingri zinātniska, 6 - populāri zinātniska satura. Populārie publicēti pa dalai ikdienišķāa presê, pa dalai atsevišşāas brošūrās, 5 latviešu, I krievu valodā. Ja nemaldos, šis ir pirmais gadījums, kur no personām, kas reflektē uz augstskolas mācības spēka vietu, iesniegti arī populāri zinātniski darbi. Man škiet, ka tādi raksti nevar noderēt reflektantu zinātniskā stāža nosacišanai, kamdēl tie turpmāk nebūtu pielaižami. Populāriem rakstiem vairāk piederīga publicistika, mazāk nopietni zinātniska mēraukla, jo zinātniskai noteiktïbai nereti jāpiekāpjas pret popularitâtes vajadzībām.

Daži Dr. med. Sniķera raksti latviešu valodā ir tulkojumi un pārstrādājumi no citâm valodām pa dalai uzsaukumu veidā, nodrukāti cīnai ar veneriskām

5 Stradings J., Cēbere D. Neuzrakstīta Rīgas augstskolu vēstures lappuse: 1910. gada ierosinājums dibināt Medicīnas akadēmiju Rīgā // Latvijas Vēstures Institūta Žurnāls. $-2000 .-1 . \mathrm{nr}$. - 97.-125. Ipp.

6 LVVA, 7427. f., 6. apr., 390 .1., 18. Ip.

7 Turpat, 50. lp. 
slimībām. Plašākai brošūrai "Karš un veneriskâs slimības" ir loti nenogludināta, pat klūdaina latviešu valoda; bez tam daudz drukas klüdas, arī interpunkcijā.

No speciāli zinātniskiem rakstiem viens vācu, citi krievu valodā. Vislielākā dala no viņiem ir kazuistiski novērojumi. Interesantākie sarakstîti laikā, kad Dr. med. Snikers strādāja prof. Pavlova klīnikā. Plašāki ir darbi par jodipinu pie sifilisa, par lichen scrofulosorum etioloǵiju un dabu un par spermatozoīdu krāsošanu. No viñiem redzams, ka autors pārvalda mikroskopiskas patoloğiski anatomiskas izmeklēšanas metodes, pie jautājumu noskaidrošanas plašā mêrā iepazinies ar attiecīgo literatūru, ka vinš iedzilinās stādītās problēmās un apdomīgs savos gala slēdzienos, kaut gan šie darbi nav cēluši gaismã jaunus zinātniskus faktus un nav norādījuši uz jauniem pētījumu celiem.

Dr. med. J. Alksnis. 24./XII 1920." 8

Domājams, ka tik kritiska, lai arĩ visumā objektīva, atsauksme ir izraisījusi noteiktu rezonansi, tālab fakultātes sēdē 1921. gada 17. janvārī J. Alksnis atsacījās no savas vietas komisijā, kurai jāspriež par P. Sniķera darbiem, un viņa vietā tika iecelts ķirurgs docents (vēlāk - profesors) Jānis Jankovskis (1876-1925)9.

Bet pa to laiku 1921. gada 7. janvārī fakultāte bija vienojusies par katedru sastāvu, kurā tika paredzēts, ka Ādas un venerisko slimību katedrā strādās viens docents (bet ne profesors!) un divi asistenti ${ }^{10}$.

Tālāk fakultātes sēdē 1921. gada 24. janvārī tika atzīts, ka P. Snikers, Oskars Voits (1866-1959), Gustavs Reinhards (1868-1937) un Ādams Butulis (1860-1938) gan esot piedalījušies fakultātes organizēšanā, bet neesot tikuši ievēlēti noteiktu priekšmetu docēšanai ${ }^{11}$.

Pēc mēneša, 28. februārī, apspriežot P. Sniḳera ievēlēšanu, fakultāte atgriezās pie sava 1919. gada 9. decembra lêmuma P. Sniḳeru uzskatīt par profesoru, bet tas neesot ticis iesniegts Organizācijas padomei apstiprināšanai, jo viṇš tajā laikā neesot lasījis lekcijas ${ }^{12}$. Atbildes runā P. Sniḳers plaši aplūkoja savus nopelnus un pazinoja, ka pieñem ievēlēšanu tikai par profesoru, bet ne docentu ${ }^{13}$.

Jautājumu atlika līdz nākamai sēdei 1921. gada 7. martā, kad atkal norisa plaša

\footnotetext{
8 Turpat, 413. 1., 13. Ip.

${ }^{9}$ Turpat, 390. 1., 56. Ip.

${ }^{10}$ Turpat, 55. lp.
}

11 Turpat, 57. lp.

12 Organizācijas padomes 1920. gada 21. janvāra protokols liecina, ka $\bar{A}$. Butula, G. Reinharda un O. Voita ievēelěsana par docentiem atlikta (noraidīta), jo vin̨i vēl nelasot lekcijas, bet P. Snikera kandidatūru dekāns profesors Eduards Zarinšs (1876-1947) nemaz nav izvirzijis (LVVA, 7427. f., 6. apr., 1. I., 96. Ip.).

13 LVVA, 7427. f., 6. apr., 390. 1., 64. Ip. 
diskusija, bet komisija atteicās no P. Sniḳera darbu recenzēsanas un slēdziena došanas, jo viņš atkărtoti uzstāja par savu kandidēšanu tikai un vienīgi uz profesora nosaukumu. Savukārt docents J. Alksnis atgādināja, ka uz katedru varētu pretendēt arī Dr. med. Jēkabs Šīrons (1870-1945), tolaik jau labi pazīstams leprologs ${ }^{14}$.

Jautājums pēc kārtējās garākas diskusijas visbeidzot tika atrisināts fakultātes 1921. gada 14. marta sēdē. Vispirms, kā saistošs, tika noraidīts 1919. gada 9. decembra lēmums (par - 4, pret -3 , atturas - 2). Pēc tam docents J. Jankovskis nolasīja recenzentu komisijas atzinumu un, aizklāti balsojot ( $\mathrm{par}-8$, atturas -1 ), P. Snik̨ers tika ievēlēts par docentu ādas un veneriskās slimībās ${ }^{15}$. Pirms balsošanas no sēdes aizgāja P. Sniķera līdzbiedri G. Reinhards un Ā. Butulis (O. Voits Šai laikā jau bija Latvijas sūtnis Vācijā).

Uz P. Sniḳera rakstisku protestu kādā no nākamām sēdēm, 4. aprîlī, fakultāte reagèeja tādējādi, ka neesot iemesla grozît jau pieṇemtu lēmumu, jo klāt neesot nākuši "nekādi jauni apstākli" 16 , un P. Sniḳers bija spiests samierināties. Izglîtības ministrs docenta amatā viṇu apstiprināja ar 1921. gada 1. jūniju17.

Nākamā rudenī, 1921. gada 15. oktobrī, docents P. Sniķers nolasijja savu pirmo lekciju LU Medicīnas fakultātes studentiem ${ }^{18}$, bet Ādas un venerisko slimību klīnikas dibināšana un darbības sākums Rīgas pilsētas 1. slimnīcas 24. barakā tiek datēts ar 1922. gada 3. februāri' ${ }^{19}$, tātad vēl pēc pusgada.

Tostarp Medicīnas fakultātes sēdēs P. Sniḳeram un J. Alksnim veidojās domstarpības gan par kirurga profesora Jāna Dzirnes (1861-1931?) uzaicināšanu darbā fakultātē, kam J. Alksnis nepiekrita, gan arī par protokolu noformēßanu, jo, tos nākamā sēdē apstiprinot, tika izteiktas pretenzijas par veidu, kā viena vai otra sēdes dalībnieka izteikumi fiksēti rakstiski. Rezultātā J. Alksnis no fakultātes sekretāra pienākumiem atteicās, un viṇa vietā 1922. gada 6. februārī tika ievēlēts P. Sniḳers ${ }^{20}$.

Abu pulkvežu nesaticībai turpinoties, J. Alksnis, neguvis gandarījumu fakultātē, 1922. gada 2. oktobrī LU Goda tiesã iesniedza sūdzību par viṇu apvainojošu P. Sniķera izteikumu, bet Goda tiesa 29. novembrī pieņēma atzinumu, ka "Dr. Sniķera lietotais izteiciens ir neparlamentārisks" 21 .

Nākamā gadā, gatavojoties ievēlēšanai par profesoru, P. Sniķers jau bija ṇēmis

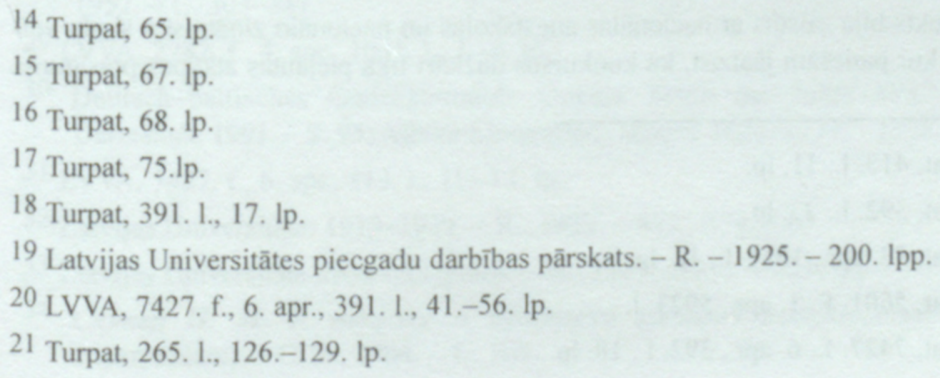


vêrā agrāko rūgto pieredzi, tāpēc savu darbu sarakstu 1923. gada 17. februārī fakultātei iesniedza ar plašiem komentāriem, piemēram, par savu disertāciju rakstot:

"Šinī darbā es pirmais visã medicīnas pasaulē sāku lietot tuberkulīnu, ärēji ierīvējot to ādā, un ievedu arī sēriju izmeklēšanas metodes (10 000 ādas griezumus), kã arī aizrādīju, ka pārmainas ādā un tuberkulozes baciļu atrašana vinnā atkarājas no slimību stadijas. Tagad visi pētnieki un dermatologi piekrīt šim uzskatam, kuru es pirmoreiz izteicu 1904. gadā. "22

Šoreiz formalitāšu kārtošana norisinājās bez jebkādas aizkeršanās - 1923. gada 19. februārī P. Sniķers vienbalsīgi tika ievēelēts par profesoru ${ }^{23}$ un amatā apstiprināts ar 7. martu ${ }^{24}$. Ja vēl ņem vērā, ka tieši sajā laikā - 1923. gada 1. aprīlī - viṇš tika paaugstināts par ārstu generāli ${ }^{25}$, tad četrdesmit septinu gadu vecumā P. Sniķers bija sasniedzis abas maksimāli iespējamās virsotnes: akadēmiskā karjerā - profesors, bet militārā - generālis, un jādomā, ka abas paaugstināšanas bija savstarpēji saistītas.

Pārlūkojot P. Sniķera akadēmiskās virzības gaitu, nebūtu pareizi viṇa likstas saistīt tikai ar divu fakultātes mācỉbspēku cilvēciskām pretišķībām vai arī, teiksim, J. Alkšña stingro principialitāti un P. Sniķera stūrgalvību. Fakultăte bija jauna, būtībā tika būvēta tukšã vietā un, gods godam, savus mãcībspēkus tā izraudzijjās rūpīgi, katru no kandidatūrām izvērtējot stingri un nopietni. Turklāt tas notika pirmo reizi, un Šis darbs bija jāveic pamatīgi, lai vēlāk nebūtu jāpiejauj vai jālabo k|ūdas, atsaucoties uz pazeminātiem kritērijiem agrāk. Jo P. Sniķers bija pirmais no pašu vidus, kas tika paaugstinăts par profesoru, un līdz ar to, labi noprotams, kā pirmajam, izejot procedūru, viņam klājās grūtāk. Pārējie fakultātes profesori tolaik bija atnācēji no citâm augstskolām jau ar pietiekamu akadēmisku stāžu, kura P. Sniķeram un vēl dažiem citiem topošajiem profesoriem pagaidām trūka, turklāt nā̄aās ievērot tradicionālo pakāpenību avansēšanas gaitā. Arī citi pretendenti uz citām katedrām, piemēram, jau minētie profesori J. Alksnis un J. Jankovskis, ejot cauri pat atkārtotiem konkursiem, dabūja uzklausīt loti stingru, kritisku un, gribētos teikt, arī pietiekami objektīvu vērtējumu par savu piemērotību fakultātei. P. Sniķers uz savu katedru bija vienīgais pretendents, bet uz Fakultātes ḳirurg̀ijas katedru, par kuras vadītāju k|uva J. Alksnis, 1923. gadā izsludinātajā konkursā bija pieteikušies 11 kandidāti ( 9 profesori un 2 docenti) ${ }^{26}$.

Cits aspekts bija saistîts ar nacionālas augstskolas un nacionālo zinātnisko skolu veidošanu, kur patiešăm jāatzīst, ka konkursos dažkārt tika piejautas atkāpes prasīguma

\footnotetext{
22 Turpat, 413.1., 11. Ip.

23 Turpat, 392. 1., 23. lp.

24 Turpat, 13. apr., 1611. 1., 18. Ip.

25 Turpat, 5601. f., 1. apr., 5923. I.

26 Turpat, 7427. f., 6. apr., 392. I., 18. lp.
} 
zin̄ā latviešu zinātniekiem ar cerỉbu, ka augot vinii attaisnos sevi. Medicinas fakultătē klīniskās katedras tika aizvietotas galvenokārt ar latviešiem, ko mazāk var teikt par teorētiskām disciplīnām. Arī, pārlūkojot dažus citus vietējos speciālistus, kas pietiekami labi pārvaldīja latviešu valodu, priekšroka tomēr tika dota latviešiem, bet ne cittautiešiem (vācbaltiešiem, ebrejiem, krieviem). P. Sniķeram konkrētā situācijā konkurents varētu būt bijis Rīgas pilsētas 1. slimnīcas ãdas un venerisko slimību nodalas dibinātājs un vadītājs Dr. med. Georgs fon Engelmanis (1863-1945), taču viņa kandidatūra netika ne izvirzita, ne arī aplūkota. G. fon Engelmanis bija pieredzējis praktizējošs ārsts un vairāku zinātnisku darbu autors ${ }^{27}$; sabiedriskā jomā vēl pirms Pirmā pasaules kara viṇ̌̌ bija daudz paveicis veneriskãs saslimstỉbas un prostitūcijas ierobežošanā Rīgā. Situācija tika atrisināta 1922. gadā, sadalot 1. slimnīcas ādas un venerisko slimību nodalu, kurā turpmāk pusi aiznēema P. Sniķera vadītã universitātes klīnika, bet otru pusi - G. fon Engelmaña jaunizveidotā urologijijas noda|ja ${ }^{28}$. Tầ bija pirmā specializētā sava profila noda|a Latvijā, un G. fon Engelmanis ar labām sekmēm to vađīja lìdz 1934. gadam ${ }^{29}$, bet 1939. gadā pārcēlās uz dzīvi Vācijāa ${ }^{30}$.

Atgriežoties pie J. Alkšņa atsauksmes par P. Sniḳera zinātniskiem darbiem, rodas jautājums, vai recenzents ir bijis pietiekami taisnīgs un objektīvs savā vērtējumā. Fakultātei 1923. gadā ar komentāriem iesniegtajā P. Sniḳera darbu sarakstā ir minēti 25 nosaukumi ${ }^{31}$, tie paši arī LU desmit gadu darbības pārskatā 1929. gadā $\bar{a}^{32}$, bet divdesmit gadu darbības pārskatā 1939. gadā P. Sniḳera publikāciju kopskaits ir pieaudzis līdz $33^{33}$.

Pati svarīgākā un būtiskākā ir 1904. gadā aizstāvētā disertācija "Par papulonekrotiskā tuberkulīda būtỉbu" un pat ne disertācija pati, bet gan niecīgs fragments no tās, kurā fiksēta apsārtuma veidošanās sešiem pacientiem pēc tuberkulīna ziepju ierīvē̌anas ādā, vienlaikus pētniekam pašam un veselam klīnikas kalpotājam Šādai reakcijai izpaliekot ${ }^{34}$. Taču ne jaunais zinātnieks, ne arī viṇa pieredzējušais Šefs profesors Timofejs Pavlovs (1860-1932), ne ziepju gatavotājs, citkārt loti vērīgais

27 Brennsohn I. Die Aerzte Livlands. - Mitau, 1905. - S. 149.

28 Гольдберг В. К. К истории развития урологии в 1-й рижской городской больнице // Труды Первой рижской городской клинической больницы. - Р. 1957. - C. 303-347.

${ }^{29}$ LVVA, 2782. f., 4. apr., 1031. 1., 1.-6. lp.

30 Deutsch-baltisches Gedenkenbuch: Unsere Toten der Jahre 1937-1947. Darmstadt, 1991. - S. 95; Album Livonorum: Dorpat 1822-1939. - 1958. - S. 240.

${ }^{31}$ LVVA, 7427. f., 6. apr., 413. 1., 11.-12. lp.

32 Latvijas Universitāte: 1919-1929. - R., 1929. - 473.-474. lpp.

${ }^{33}$ Latvijas Universitāte divdesmit gados. - R., 1939. - 2. d. - 425. Ipp.

34 Сникер П. М. К вопросу о сущности Lichenis scrofulosorum (лишая золотушных). - СПб., 1904. - С. 105. 
farmaceits un mikrobiologs Kārlis Krēslinš (1860-1929), ne Pēterburgas ārstu sabiedrïba, kura, domājams, arī bija iepazinusies ar disertāciju, to pienācīgi novêrtēt nespēja, un potenciālais atklājums, kam bija nepieciešams daudz plašāks eksperimentāls vispārinājums pirms drošas ieviešanas klīniskās diagnostikas praksê,, jaunajam censonim aizgāja secen, pasaules slavu un laurus trīs gadus vēlāk atvêlot vâcu pediatram Ernstam Moro (1874-1951). Būtībā kritiku pat neiztur viedoklis, ka P. Sniķers tomēr to novērojis pirmais, jo pēc analogijas, ka pelējuma sēnes antibiotisko darbības efektu daudzi zinātnieki ir novērojuši jau krietnu laiku pirms penicilīna atklāšanas, to saista tikai ar Aleksandera Fleminga (1881-1955) vărdu. Vēlāk, apjautis, kas vinam pagājis garām, P. Sniḳers, sarūgtinājumā akcentējot, rakstịja, ka savā disertācijā viņ̧ pirmais "ieteicis lietot tuberkulīmu, ierīvējot to ādā kã diagnostikumu, un Moro to pašu darījis 1908. g., tā ka prioritāte pieder P. Snikseram"35.

Visnotal jāpiekrīt J. Alksnim, ka P. Sniḳera kā pētnieka darbība galvenokārt saistāma ar Kara medicīnas akadēmiju, jo viṇa nozīmīgākie darbi (lîdztekus disertācijai arī par sifilisa terapiju ar jodipīnu, par spermatozoīdu krāsošanu) publicēti laikposmā no 1904. līdz 1910. gadam. Sagrupējot P. Sniķera publikācijas pa noteiktiem laikposmiem, uzskatāmāka k|ūst vina interešu virzỉba.

Līdz LU nodibināšanai 1919. gadā P. Sniķers savā darbu sarakstā ir minējis 20 nosaukumu: disertāciju, 4 rakstus krievu un vācu zinātniskos izdevumos, 8 referātus par kazuistiskiem gadījumiem vai jaunieviesumiem klīniskā praksē, kas nolasīti Rīgas Krievu ārstu biedrỉbas sēdēs un publicēti tās protokolos (ieskaitot klīniskas demonstrācijas), 3 rakstus kara medicīnas izdevumos un 4 populārmedicīniskus darbus, to skaitā brošũras "Lipīgas slimības" (Rīga, 1915) un "Karš un veneriskas slimỉbas" (Limbaži, 1917).

Savukārt laikposmā no 1919. līdz 1939. gadam P. Sniḳera publikāciju sarakstā rodami 13 darbi: divi Latvijas ārstu kongresos (par venerisko slimību izplatību un prostitūciju un par ārstiem speciālistiem) un viens Lietuvas ārstu kongresā (par ādas tuberkulozi) nolasîts referāts, viens publicistisks darbs LU Rakstos (venerisko slimību iespaids uz Latvijas nākotni), viena recenzija, 6 populārzinātniski darbi (viens no tiem nepublicēts rokraksts), tostarp brošūras "Laulība un dzimuma slimības" (Rīga, 1920) un "Kā izsargāties no veneriskām slimībām" (Rīga, 1923), kã arī divi ar specialitāti nesaistîti raksti ikdienas presē.

Diskutējot par to, kas gan ir pētījums jeb zinātnisks darbs, Medicīnas fakultāte profesora P. Sniḳera kā dekāna vadỉbas laikā 1938. gada 5. decembrī pieṇēma sãdu atzinumu:

"Zinātnisks darbs ir darbs, kurā autors vismaz izpaudis kädu jaunu domu, teicis kādu jaunu vārdu vai arī devis jaunu faktisku materiālu, kas varētu noderēt par bāzi un dot ierosmi tāläkiem pētījumiem. "36

${ }^{35}$ Latvijas Universitāte divdesmit gados. - R., 1939. - 2. d. - 425. Ipp. [Šajā krājumā ietvertãs biogrāfijas mãcỉbspēki rakstīja paši.]

36 LVVA, 7427. f., 6. apr., 408. 1., 30. lp. 
Tālab jāsecina, ka savā profesora darbības laikā kopš 1923. gada P. Sniķers tomēr nav veicis nopietnāku pētniecisko darbu klīnikā, nerunājot nemaz par eksperimentāliem pētījumiem, jo vina ši laika publikācijām galvenokărt piemīt publicistisks vai popularizējošs raksturs. Arī mācību grāmatu studentiem savā specialitātē vinšš netika sagatavojis, lai gan tas bija LU Medicīnas fakultātes profesora pienākums. Proti, 1935. gadā sakarā ar mācību programmu mainu, Latvijā nenotika vidusskolu izlaidums, un Medicīnas fakultāte saai gadā nolēma jaunus studentus neuznemt ${ }^{37}$. Izveidojās t. s. brīvais jeb tukšais gads, kas secīgi gāja caur studiju kursiem un kura laikā no studentu apmācības brīviem profesoriem fakultăte uzdeva sagatavot mācību grāmatas. Da|a profesoru, īpaši medicīnas teorētiskajās disciplīnās, šo uzdevumu izpildīja, un arī P. Sniḳers, kad pienāca viña laiks, 1939. gada 16. maijā fakultātei ziṇoja, ka brīvã gada laikā ir iecerējis sarakstīt mācỉbu grāmatư ${ }^{38}$. Bet 1941. gada

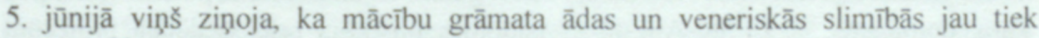
gatavota ${ }^{39}$, taču iecere palika nerealizēta, ko varētu attaisnot ar kara laika apstākliem. Ja arī profesors P. Sniḳers zinātniskā darbā savā klīnikā pats bija mazaktîvs, tad izvirzās jautājums par vina līdzstrādnieku darbību, proti, vai tika izveidota un vai pastāvẹja P. Sniķera zinātniskā skola dermatovenerologijāa. Katedrā bija trīs privātdocenti: J. Širons, Jānis Brants (1889-1944) un Jūlijs Galejs (1884-1951); abiem pēdējiem disertācijas aizstāvēšanas procedūrā 1929. gadā P. Sniḳers bija trešais oponents.

Leprologu J. Šĩronu nosaukt par P. Sniḳera skolnieku nav iespējams kaut vai tālab, ka gadu ziṇā viṇ̌ bija vecāks par profesoru, savu disertāciju bija aizstāvējis jau 1914. gadā $\overline{40}^{40}$ un, kā jau minēts, varētu pat pretendēt uz katedras vadību, ja situācija 1921. gadā P. Sniķeram būtu atrisinājusies nelabvēlīgi. J. Šîrons ar P. Sniķera vadīto klīniku 1. slimnīcā tieši saistīts nebija un studentiem no 1922. līdz 1938. gadam docēja leprolog̉iju Rīgas leprozorijā, kura direktors viṇš bija.

Arī J. Brants ar P. Sniḳera vadīto klīniku ne pirms, ne pēc ievēlē̌̉anas par privātdocentu 1930. gadā $^{41}$ tieši saistīts nebija un savus pētījumus veica patstāvīgi. J. Brants bija Aleksandra Augstumu slimnīcas direktors un tās venerisko slimību noda|ā vadīja zobārstniecības studentu apmācību. Pētniecisko interešu ziṇā J. Brants bija patiešām spožākais dermatovenerologs starpkaru posma Latvijā, taču akadēmiski pakāpties augstāk nevarēja, jo vakance bija aiznemta.

Savukārt J. Galejs, kas jau kopš sākuma strādāja profesora P. Sniķera klīnikā, savam doktora darbam bija izvēlējies farmācijas robežjomas tēmu, jo, pirms k|ūt
37 Turpat, 404. 1., 21. Ip.
38 Turpat, 408. 1., 68. Ip.
${ }^{39}$ LVA, 1340. f., 1. apr., 86. 1., 19. lp.
${ }^{40}$ LVVA, 7427. f., 13. apr., 1684. 1., 34. Ip.
41 Turpat, 251. 1., 12. Ip. 
par ārstu, 1904. gadā bija ieguvis aptiekāra palīga diplomu un vairākus gadus studējis ķīmiju. 1940. gadā no darba LU viņš aizgāja ${ }^{42}$, vietā stājoties Valērijam Silarājam (Solovjovam, 1915-1974). Savukārt viņšs, līdzīgi katedras asistentei Mildai Knostenbergai (1896-?), kas 1935. gadā ${ }^{43}$ nomainīja Minnu Mazkalniņu (1892-1956), savos zinātniskos centienos bija mazpamanāms.

Zinātniskai skolai ir nepieciešams turpinājums un tradīcijas, kas šai gadījumā pễc profesora P. Sniḳera nāves 1944. gadā izpalika. Pēc kara J. Šĩons un J. Brants jau bija miruši, tālab katedru amatu savienošanas kārtỉbā aizvietoja patologanatoms bez zinātniska grāda Ernests Apse-Apsītis (1898-1980), kas bija profesora Romana Adelheima (1881-1938) skolnieks ${ }^{44}$. V. Silarājs un M. Knostenberga bija nokjuvuši Austrālijā ${ }^{45}$, bet M. Mazkalniņa pẽc pātraukuma atgriezās katedrā un no 1944. lĩdz 1948. gadam bija asistente ${ }^{46}$. J. Galejs 1941. gada 14. jūnijā tika deportēts ${ }^{47}$, bet pēc kara, domājams, ar LPSR Augstākās padomes prezidija priekšsēdētāja profesora Augusta Kirhenšteina (1872-1963) gādību48 no Soḷikamskas 1946. gadā atgriezās Rīgā. Dekāns profesors Pauls Stradiṇš (1896-1958) J. Galeju iesaistīja agrākā darbā katedrā, no kura viṇs 1948. gadā tika atbrīvots "stundu fonda samazināšanas dēê"49. Šajā laikā, proti, 1947. gadā, J. Galejs piedalījās konkursā uz Ādas un venerisko slimību katedras vadītāja vietu, taču tika atzîts par nepiemērotu, īpaši pedagogiskā ziṇāoñ

Tālab kopumã par profesoru P. Sniķeru jārunā ne tik daudz kā par zinātnieku vai zinātniskās skolas izveidotāju, cik par izcilu organizatoru (Latvijas armijas sanitârā dienesta izveide un vadība, vairāki amati un pienākumi LU un tās Medicīnas fakultātē, kã arī dažādu biedrỉbu un sabiedrisko organizāciju dibināšana, vadība, dalība to darbā) un prasmīgu, veiksmīgu, dāsni atalgotu ${ }^{51}$ praktizējošo ārstu.

Otrs jautājums, kas jāaplūko šai rakstā, ir saistīts ar fakultātes studiju programmām un P. Sniḳera viedokli šai ziṇã.

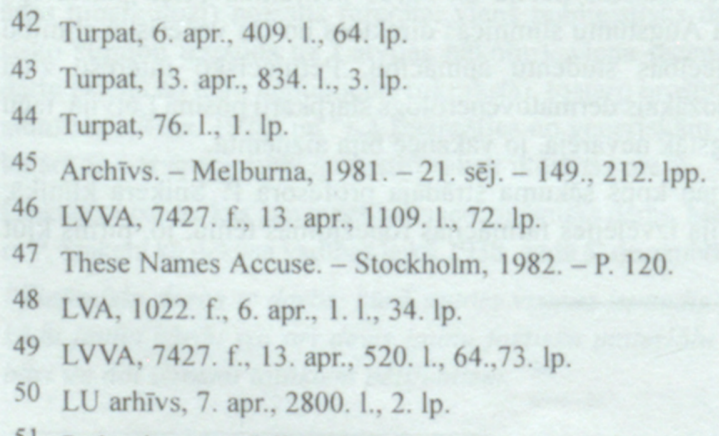

51 Padomju varas laikā 1940. gadā tika nacionalizēti P. Sniḳera namīpašumi Rīgā, Brīvỉbas ielā 15 (resp., 39), Visbijas prosp. 7, Mūkusalas ielā 29/31, un trīs viṇam piederošas vasarnīcas Ḳemeros, kã arī nams Lỉbekas ielã 13, kas piederēja viṇa dzìvesbiedrei, un dēla nams Tallinas ielā 77 (LVVA, 7427. f., 13. apr., 1611. 1., 64. Ip.). 
Sasniedzis tolaik noteikto 58 gadu maksimālo vecumu un noslēdzis karavīra dienestu 1933. gadā, viṇš pilnībā varēja iesaistīties fakultātes darbā. Līdz tam profesors P. Sniķers bija LU ārštata mācībspēks pat neraugoties uz to, ka vadīja katedru un klīniku, kã arī ieṇēma dažus citus sỉkākus vēlētus amatus fakultātē un augstskolā, jo viņa pamatdarbavieta bija Latvijas armija.

P. Sniḳera lielo pieredzi vadošā darbā un organizatora prasmi fakultāte nekavējās izmantot un jau tajā pašã 1933. gadā ievēlēja par dekānu ${ }^{52}$. Šo posteni viṇš ieṇēma divus termiṇus: no 1933. līdz 1935. gadam un no 1937. līdz 1939. gadam. Atbilstīgi tolaik piennemtai kārtỉbai, dekānu ievēelēja uz diviem gadiem un ne vairāk kā trīs reizes, pie tam starp terminiiem vajadzēja būt atstarpei (proti, nedrîkstēja ievēelêt uzreiz uz nākamo terminuu, bet vismaz divi gadi bija jāizlaiž). No fakultātes pirmskara dekāniem uz trim termiṇiem tika ievēlēts vienīgi psihiatrs profesors Hermanis Buduls (1882-1954), uz diviem - profesors R. Krimbergs un profesors P. Sniķers, nosacīti (ieskaitot vācu laiku) - arī anatoms profesors Jēkabs Prīmanis (1892-1971).

Profesora P. Sniḳera dekāna darbības laiks fakultātē bija relatĩvi mierīgs, jo tā jau bija nostabilizējusies un sekmīgi strādāja, vien trīsdesmito gadu beigās sāka iezīmêties un izpausties pirmā paaudžu maiṇa, katedru priekšgalā stājoties pašu fakultātể izaudzinātiem talantīgiem jaunās paaudzes zinātniekiem.

Dekāna darbības laikā P. Sniḳeram vismaz divreiz nācās saskarties ar ska|ākiem pārmetumiem, kas varētu liecināt par viṇa kā karavīra raupjāku, robustāku izturēšanos un raksturu.

Ginekologs profesors Ernests Putniṇš (1867-1962) LU Goda tiesai sūdzējās, ka 1939. gada 22. februārī, apspriežot Dr: med. Pētera Ābeles (1893-1986) habilitēšanās iespēju LU Padomē, dekāns P. Snikers esot izteicies stipri aizskarošã veidā par profesoru. Pēc P. Sniḳera attaisnošanās, kas E. Putniņu neapmierināja, Goda tiesa 1939. gada 2. jūnijā nolēma, ka jāatvainojas vēlreiz un jāizlīgst ${ }^{53}$.

Savukārt otram notikumam bija vēlāka atskaṇa, proti, 1942. gada 19. jūnijā ginekologs $\mathrm{Dr}$ : med. Aleksandrs Baidiņš (1888-1962) fakultātei sūdzējās, ka P. Sniḳers kā dekāns 1939. gadā noraidījis vina habilitācijas darbu. P. Sniḳers attaisnojās, ka tolaik esot saṇēmis "norādījumu no augstākas instances" ${ }^{4} 4$, turklāt A. Baidinam esot pastāvējusi iespēja dekāna lēmumu savlaicīgi pārsūdzēt, ko viṇš

52 LVVA, 7427. f., 13. apr., 1611. 1., 33. lp.

53 Turpat, 6. apr., 265. 1., 353.-374. Ip.

54 Rīgas Kara slimnīcas noda|as priekšniekam ārstam pulkvedim leitnantam A. Baidinamam at|auju habilitēties kopā ar cildinošu rekomendāciju 1938. gada 10. novembrī izsniedza Latvijas armijas komandieris g̀enerālis Krišjānis Berķis (1884-1942) un kara sanitārais priekšnieks ărsts pulkvedis Alberts Brambats (1881-1943?) (LVVA, 7427. f., 13. apr., 110. 1., 12. Ip.), tālab jādomā, ka P. Sniḳers atsaucies uz kādu citu instanci. 
neesot darīijis. Fakultāte nolēma uzskatīt lietu par izbeigtu ${ }^{55}$. Līdzīgs lēmums tika

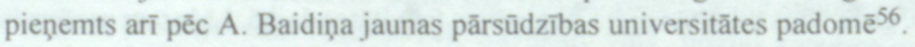

Atgriežoties pie aplūkojamās tēmas, pirmais fakultātes studiju plāns tika apstiprināts jau 1919. gada 15. septembrī un paredzēja piecgadīgu apmācību pēc agrākās Krievijas medicīnas augstskolu parauga.

Taču jau 1922. gada 29. maijā fakultāte mācību laiku nolēma pagarināt no pieciem uz sešiem gadiem, ko LU Padome apstiprināja 30. jūnijāā7. Turpmāk, 1930. gada 7. aprīlī, pēc dekāna H. Budula priekšlikuma tika izdarīta korekcija un nolemts, ka lekcijas jālasa pirmos piecus gadus, bet sestais galvenokārt jāveltĩ klīniskai praksei, vienīgi vakaros lasot neobligătas papildlekcijas ${ }^{58}$.

Tostarp bija pienācis profesora P. Sniķera dekāna laiks. Pēc profesora J. Prīmaña priekšlikuma 1933. gada 11. septembrī dekāns profesors P. Sniķers ieteica svarīgu pagriezienu - no kursu sistēmas pāriet uz priekšmetu sistēmu. Fakultâtē tas tika uzṇemts ne visai vienprātīgi, jo izraisījās plaša diskusija, saṇemot gan atbalstu, gan arī iebildumus.

Tomēr jauno studiju programmu fakultāte 1937. gada 26. aprīî̄ nolēma ieviest sākot ar 1937./38. gadu, tātad ar dekāna P. Sniķ̣era otro darbības termiṇu. Nolēma, ka pirmã un otrã kursa studenti sāks strādāt pẽ̃ jaunās programmas tūlît, bet vecāko kursu studentiem vecā programma pakāpeniski tiks sašaurināta, lai jaunā programma, resp., pēc priekšmetu sistēmas veidotā, tiktu pilnỉbā un galīgi ieviesta 1940./41. gadā.

1939. gada pavasarī apstiprinātais mãcību plāns paredzēja sešu gadu studijas, kas tika dalītas divos posmos pa trim gadiem katrā. Studentiem tika dota iespēja labāk iedziļinâties atsevišķ̧os viṇus vairāk interesējošos priekšmetos, bet nebija obligāti jāpierakstās uz visiem atbilstīgā gadā paredzētiem priekšmetiem, proti, tika dota zināma brīvas izvēles iespēja. Taču bija jāievêro noteikta secỉba, kāda nepieciešama atsevišķ priekšmetu apguvē. Lìdz ar to viena vai divu nenokārtotu eksāmenu dē| vairs nebija jāpaliek uz otru gadu tajā pašā kursā, kã tas bija pie kursu sistēmas, lai gan, agrāk vai vēlāk, visi paredzētie eksāmeni kopumā bija jānoliek. Otrajā studiju posmā bija paredzētas divas obligātās divmēnešu vasaras prakses

LVVA, 7427. f., 7. apr., 101. 1., 85.-86. Ip.

56 Turpat, 35. 1., 6., 13. Ip. Šai gadījumā gan ne tik daudz izpaudās A. Baidiña personīgais aizvainojums, cik fakultātē iestājusies bīstamā klanu cīna starp Tērbatas universitātes un Kara medicīnas akadēmijas audzēkniem (korporācijāmm "Lettonia" un "Fraternitas Metropolitana"), kas savu apogeju sasniedza 1941./42. gadā un, launākã gadījumã, varētu novest fakultāti pat līdz sairšanai, taču šis mācībspēku konflikts un P. Sniḳera pozĩcija tajā plašāk jāaplūko citā rakstā.

LVVA, 7427. f., 6. apr., 2. 1., 51. lp.

Latvijas Universitāte divdesmit gados. - R., 1939. - 1. d. - 660.-662. Ipp. 
kādā aarstniecības iestādē. Sestajā mãcību gadā bija paredzētas tikai praktiskās nodarbības, iznemot lekcijas medicīnas vēsturē un eigēnikā, kuras lasīja vienu stundu nedē|ā̄

Taču pilnībā pāriet uz jauno programmu fakultāte nepaspēja, jo jau tūlīt pēc padomju okupācijas ar 1940./41. gadu tika stingri noteikts strādāt pēc padomju medicīnas augstskolu programmas, kuru 1940. gada 13. jūnijā bija apstiprinājusi PSRS Tautas komisāru padomes Augstākās izglîtỉbas lietu komiteja. Šì programma bija veidota pēc kursu sistēmas ar piecgadīgu (ne sešgadīgu, kā LU) mācību laiku. Daži piemēri no šis programmas: marksisma un leṇinisma pamati - 220 stundu, politiskā ekonomija - 160, fiziskā sagatavošana - 185, kara sanitārā sagatavošana - 183, toties pediatrija -132 , oftalmologija -93 , psihiatrija -72 stundas $^{60}$. Tā kā tūlîtēja pāreja radītu sarežg̀ijjumus, iznēmuma kārtā piecgadīgo programmu nolēma ieviest ar 1941./42. gadu ${ }^{61}$, kas vairs nevarēja notikt sakarā ar karadarbỉbas iestāsanos.

Vācu laikā fakultāte centās atgriezties pie agrākās studiju programmas, taču kara apstākli nenovēršami radīja dažādas izmaiņas. Tiesa gan, studiju laiks (kā PSRS kara laikā) oficiāli saīsināts netika, taču daudzi vecāko kursu studenti priekšlaikus tika mobilizēti armijā feldšera darbam.

Pêc kara pirmos divus gadus studiju programmā valdīja jukas, par pamatu ṇemot to pašu piecgadīgo padomju programmu un cenšoties to pielāgot Latvijas tradicionālajai medicīnas studiju sešgadu programmai. Šai ziṇã tika izteiktas visai asas savstarpējās pretenzijas starp Latvijā palikušajiem fakultẫtes mācībspēkiem un iebraucējiem, kas strauji ien̦ēma vadošas pozīcijas fakultātế ${ }^{-62}$. Taču daudzmaz pieñemams risinājums tika gūts 1947. gadā, kad arī PSRS pãrgāja uz sešgadīgu apmācỉbu. Daži no "vecajiem" mācībspēkiem vēl centās pieturēties pie pirmskara programmām vismaz savos priekšmetos, taču ar administratīvu bardzỉbu tas strauji tika izskausts. Studiju plāni un programmas mūsdienīgākā interpretācijā aplūkojamas pēc 1998. gada, kad Latvijas Universitātē pēc gandrīz pusgadsimta pārtraukuma tika atjaunota Medicīnas fakultāte. Šajā procesā tika ievēroti modernas eiropeiskas universitātes darbības principi, par galveno prasību izvirzot to, ka studentam jāveidojas akadēmiskā, dzili inteliğentā, demokrātiskã un brīvā vidē.

Fakultātes studenti mūsdienās aktīvi piedalās savas studiju programmas veidošanā, apgūstot $A$ - obligātos, $B$ - obligātos izvēles, $C$ - brīvas izvēles kursus. Tas ir iespējams tikai universitātēs, kurās piedãvā plašu studiju programmu klāstu vărda universitas vistiešākajā nozīmē.

59 Turpat, 663.-666. lpp.

60 LVA, 1340. f., 1. apr., 65. 1., 1. lp.

61 Turpat, 89. 1., 137. 1p.

62 Vịksna A. Rīgas Medicīnas institūta dibināšana // Latvijas Ārsts. - 1997. - 11. nr. 699. -709. Ipp. 
Otra svarīga iezīme ir pāreja uz kredītpunktu sistēmu, kas ir izprotama un pielīdzināma visās Eiropas augstskolās. Tādējādi tas łauj studentiem pārvietoties, studējot visā plašajā Eiropas telpā, apgūt vienu vai vairākus priekšmetus citās valstīs, un tas LU Medicīnas fakultātẽ pašlaik jau reāli notiek.

Fakultātes pamatprincips ir priekšmetu sistēmas ieviešana studiju programmā, kas studentam lauj savā gaitā doties uz priekšu, neapstājoties kādas nenokārtotas ieskaites vai eksāmena dē], ko būs iespējams paveikt vēlāk.

Jā, bija jāpaiet vairāk nekā sešdesmit gadiem, lai laika loks noslēgtos un fakultāte atgrieztos jau pie pirms kara izdiskutētiem jautājumiem, kuru sekmīgu risinājumu profesors P. Sniḳers kã dekāns bija uzsācis 1937./38. akadēmiskā gadā.

The Activities of Professor Pêteris Snikers at the Faculty of Medicine of Latvia's University (Summary)

By Uldis Vikmanis, Ingrīda Rumba, Arnis Vịsna

Based on Archive materials two problems of the activities of dermatovenerologist professor Pēteris Sniķers (1875-1944) have been critically evaluated: his progress at the Faculty of Medicine of Latvia's University as well as the plans and the curricula of the Faculty during the period of the activities of P. Snikers compared to those of our days. Several questions concerning research work at the chair headed by P. Snikers as well as his attitude towards the discrepancy among the members of his chair have been likewise reviewed in this article.

Uldis Vikmanis, Dr. habil. med., prof., LZA kor.loc.

Ingrīda Rumba, Dr. habil. med., prof.

Arnis Vïksna, Dr. habil. med., prof., LZA akad.

LU Medicīnas fakultāte

Raina bulv. 19

Rīga, LV-1586

Latvija 